\title{
Genotoxicity of Heavy Metals on Mung Bean (Vigna radiata) Seedlings and Its Alleviation by Priming with Their Lower Concentrations
}

\author{
Umme Hani, Simeen Mansoor*, Meher Hassan and Jabeen Farheen \\ Department of Genetics, University of Karachi, Karachi, Pakistan \\ Received November 7, 2019; accepted May 16, 2020
}

\begin{abstract}
Summary Due to urbanization and industrialization, heavy metals have become the common environmental pollutant throughout the world. Chromosomal studies are one of the important tools to estimate the genome damaging property of these metals. This research was done to analyze the genotoxic effects of metals such as cadmium $(\mathrm{Cd})$, nickel $(\mathrm{Ni})$, mercury $(\mathrm{Hg})$, lead $(\mathrm{Pb})$ and copper $(\mathrm{Cu})$ in mung bean (Vigna radiata) root tips. The experiment was set in such a way that mild metal treatment $(0.01 \mathrm{mM})$ was given before respective high metal treatments $(0.1$ and $0.5 \mathrm{mM})$ separately, with the aim to know whether low/mild metals can alleviate metal tolerance in mung bean seedlings. Results demonstrated that metals treatment resulted in growth and mitotic index reduction. Among all the tested metals, $\mathrm{Cd}$ was found to cause more negative effect on growth of mung bean seedlings with length of $6.12 \mathrm{~cm}$ and $13.41 \%$ mitotic Index (MI) with the highest total aberrations (27.91\%) at $0.5 \mathrm{mM}$ Cd. Positive correlation was found between mitotic index and seedling length while a negative correlation was recorded between chromosomal aberrations with mitotic index and seedling length. Among these abnormalities C-mitosis, sticky chromosomes, and disturb metaphase were the most common aberrations irrespective of the metal. Furthermore, it was also observed that seed priming with respective mild metal concentration improves the seedling length, MI, and reduces the effect of metal stress by lowering the chromosomal aberrations in both $0.1 \mathrm{mM}$ and $0.5 \mathrm{mM}$ concentrations as compared to metal stress alone.
\end{abstract}

Keywords Aberrations, Genotoxicity, Heavy metal, Mitotic index, Priming.

As constituents of earth's crust our environment naturally contains heavy metals. Among them iron, copper, cobalt, zinc, manganese are essentially required for many functions, including electron transfer reactions and as cofactors in many proteins and enzymes synthesis. Unlike other metals cadmium, lead and mercury are considered as non-essential, as they are toxic above certain concentrations. Plants have an ability to accumulate both essential and non-essential ions (Djingova and Kuleff 2000). Higher concentrations of these metals in environment and agricultural soils modify the biological properties of soil which may accumulate them in different plant tissues (Beyersmann and Hartwig 2008). Plants have major importance in the food cycle. Water, soil, and air pollution in the ecosystem accumulates heavy metals in the food web that is a risk to every living being. So it is mandatory to analyze environmental issues in plant systems. A study on roots is important to identify the toxic effects of metals, as roots are first to exposed in soil by these toxicants (Samuel et al. 2010). Some common sources of metal contamination are industrial effluents, mining activities, combustion of fuels, and use of agricultural chemicals. Reduction in mitotic index

\footnotetext{
* Corresponding author, e-mail: simeenm@uok.edu.pk

DOI: $10.1508 /$ cytologia. 85.239
}

and an increase in chromosomal aberrations can be used as parameters to calculate genotoxicity in plants. Metals reduce plant growth and found to be chromo toxic and mutagenic for various plant species (Muneer et al. 2011). It has been reported that metals are responsible to inhibit cell division in plants such as reported in barley (Liu et al. 2009) and in $V$. radiata (Muneer et al. 2011). $\mathrm{Cd}$ directly affects structural and functional properties of DNA that can be determined by different laboratory methods (Liu et al. 2009). Decrease in mitotic index was reported under Cd stress (Unyayar et al. 2006). Excess amount of $\mathrm{Cu}$ altered the nucleic acid content in plants (Rajesh and Radha 2011). It was also reported that $\mathrm{Pb}$ is more toxic than $\mathrm{Zn}$ on the basis of higher abnormalities under highest concentration and decreases the frequency of cell division (Ishido and Kunimoto 2000). In the number of studies, $\mathrm{Hg}$ was also reported as genotoxic. The metal binding ability of $\mathrm{Hg}$ with tubulin-SH makes it more genotoxic that impairs spindle formation and resulted in chromosomal mutations or aberrations $(\mathrm{Ku}-$ mar and Rai 2007). The purpose of proposed study was to evaluate the genotoxic effects of different metals on mung bean ( $V$. radiata) seedlings and the pretreatment effect of very low concentrations of respective metals in the alleviation on their high dose effect. 
Materials and methods

Mung bean germplasm (NM 19-19) was obtained from National Agricultural Research Centre (NARC), Islamabad, Pakistan. The experiment was set in Petri dishes in such a way that the effect of different metals at two concentrations $(0.1$ and $0.5 \mathrm{mM})$ was tested for their genotoxic effect. Simultaneously at the same time alleviation of each metal stress was analyzed after pre-treating seeds with a very low concentration $(0.01 \mathrm{mM})$ of metal before exposed with respective high metal concentrations. Amount of metals was calculated by the following formula;

$$
\text { Amount }=\frac{\text { Molarity } \times \text { Molecular weight } \times \text { Volume }}{1000}
$$

Twenty healthy seeds were imbibed separately in pretreatment solution of $0.01 \mathrm{mM} \mathrm{Cd}, \mathrm{Ni}, \mathrm{Hg}, \mathrm{Pb}, \mathrm{Cu}$ and distilled water (control) for $24 \mathrm{~h}$, allowed to germinate in Petri dishes with distilled water for $24 \mathrm{~h}$. Later treated with five respective metals of $0.1 \mathrm{mM}$ and $0.5 \mathrm{mM}$ concentration for $5 \mathrm{~h}$. Root tips were collected for cytological analysis. Root tips were washed with distilled water thrice and fixed in Farmer's fixative solution ( $3: 1$ absolute alcohol: glacial acetic acid) for $24 \mathrm{~h}$, later stained in $1.8 \%$ aceto-orcein according to Fiskesjo (1997) with minor modifications (Farheen and Mansoor 2019). Stained was prepared by mixing $1.8 \mathrm{~g}$ of aceto-orcein in $100 \mathrm{~mL}$ of $45 \%$ glacial acetic acid followed by boiling in a water bath for $7 \mathrm{~h}$ on a hot plate (M6). Slides were prepared and made them permanent by dipping in Farmer's fixative till the coverslip separate, later air-dried, and treated with absolute alcohol for $1 \mathrm{~min}$. Again air-dried and placed a drop of Canada balsam on the specimen present on the slide and placed a fresh glass coverslip over it. Allowed to dry completely and observed normal and abnormal cells using a compound microscope (OSK, 578). Photographs were taken by using a Nikon Eclipse E 400. Three slides/treatment were made. Two hundred cells/slides/treatment were analyzed. MI and chromosomal aberrations such as sticky chromosomes, bridges, laggard anaphase, and C-mitosis were observed and expressed in percentages through the given formula (Jairajpuri et al. 2016);

$$
\begin{aligned}
& \text { Mitotic Index }(\mathrm{MI})=\frac{\text { Number of dividing cells }}{\text { Total number of cells }} \times 100 \\
& \text { Aberration }=\frac{\text { Total number of aberrant cells }}{\text { Number of dividing cells }} \times 100
\end{aligned}
$$

Seedlings were allowed to grow for $72 \mathrm{~h}$ for growth analysis. The experiment was conducted in Complete Randomized Design (CRD) with 3 replications. Analysis of variance (ANOVA) for all parameters was performed through computer software SPSS version 20. Correlation between different parameters was also calculated.

Results and discussion

\section{Seedlings length}

There was a significant difference between the seedling lengths of mung bean under different metal treatments (Table 1). Figure 1 showed growth performance of mung bean seedlings under all metal treatments. The length of mung bean seedlings was highest in control as compared to both concentrations of each metal. However, when priming with mild concentration of respective metal $(0.01 \mathrm{mM})$ was done before $0.1 \mathrm{mM}$ and $0.5 \mathrm{mM}$ concentrations, the length was improved as compared to metal treatment without priming. More improvement was found for $0.1 \mathrm{mM}$ as compared to $0.5 \mathrm{mM}$ concentration of each metal (Fig. 2). Our results are in agreement with the work of Muneer et al. (2011) who reported that metals tend to decrease plant growth, by decreasing root and shoots length and causing visible injuries by inducing physiological disorders. Thus causes bioaccumulation and reduces plant yield (Sudhakar et al. 1992). Heavy metal in soil reduces not only the growth of vegetative parts, but affects cell division, and inducing chromosomal aberrations in Flax seeds (Dimitrova and Ivanova 2003). Presoaking in a mild concentration of respective metal $(0.01 \mathrm{mM})$ was given before 0.1 and $0.5 \mathrm{mM}$ concentrations, showed improvement in seedling length. The highest inhibition in seedling length was recorded was $41.9 \%$ for 0.1 and $67.2 \%$ at $0.5 \mathrm{mM}$ $\mathrm{Cd}$ respectively, whereas there was $12.4 \%$ and $28.3 \%$ inhibition at both concentrations of $\mathrm{Pb}$ respectively. While Seed priming helps in improving germination and growth of seeds in many crops under stress by altering certain physiological and biochemical processes (Bakht

\begin{tabular}{|c|c|c|c|c|c|c|c|c|c|c|}
\hline \multirow{2}{*}{ SOV } & \multirow[b]{2}{*}{ Df } & \multicolumn{9}{|c|}{ MS } \\
\hline & & $\begin{array}{c}\text { Seedling } \\
\text { length }\end{array}$ & MI & $\begin{array}{c}\text { Total } \\
\text { aberration }\end{array}$ & Bridges & Stickiness & Laggards & C-mitosis & $\begin{array}{l}\text { Disturbed } \\
\text { metaphase }\end{array}$ & $\begin{array}{c}\text { Abnormal } \\
\text { prophase }\end{array}$ \\
\hline Treatment & 20.00 & $37.10^{*}$ & $718.36^{*}$ & $98.95 *$ & $0.22 *$ & $3.04 *$ & $0.69 *$ & $82.80 *$ & $1.62 *$ & $11.84^{*}$ \\
\hline Error & 40.00 & 0.93 & 2.88 & 1.02 & 0.02 & 0.16 & 0.01 & 0.61 & 0.08 & 0.22 \\
\hline
\end{tabular}

Table 1. Mean sum of squares for seedling length, MI and chromosomal abnormalities on root meristematic cells of mung bean ( $V$. radiata) at different concentrations of heavy metals. 


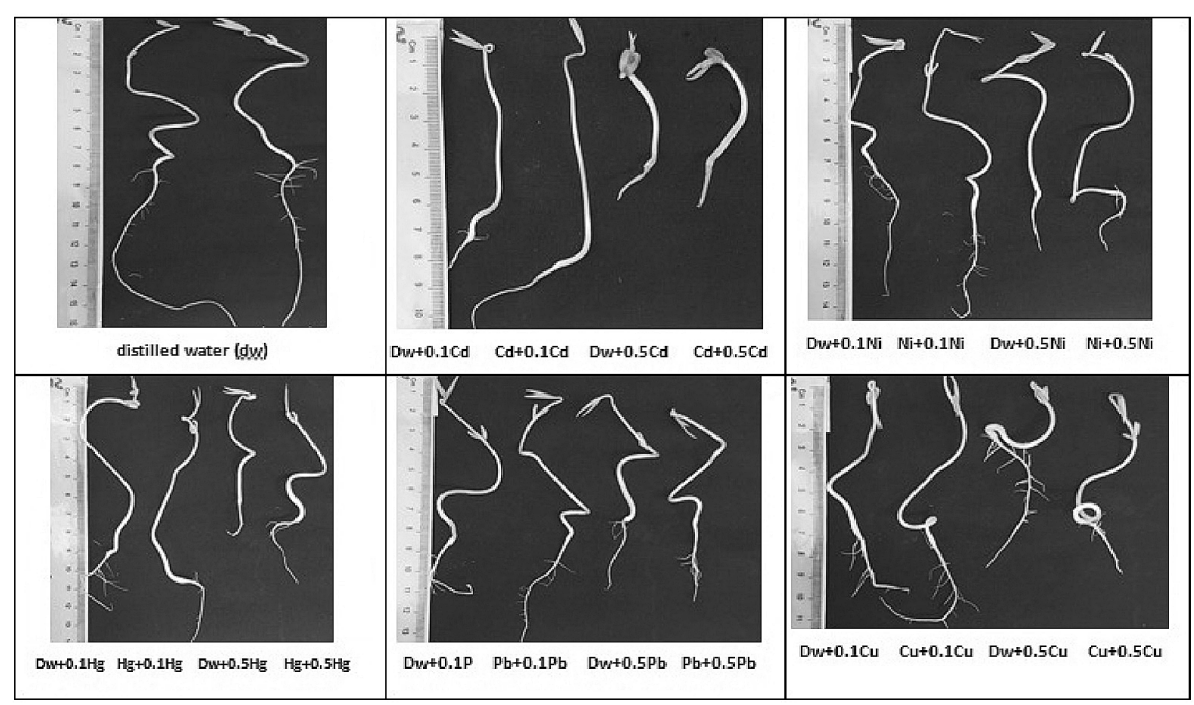

Fig. 1. Growth performance of mung bean seedlings grown under various metal treatments for $72 \mathrm{~h}$.

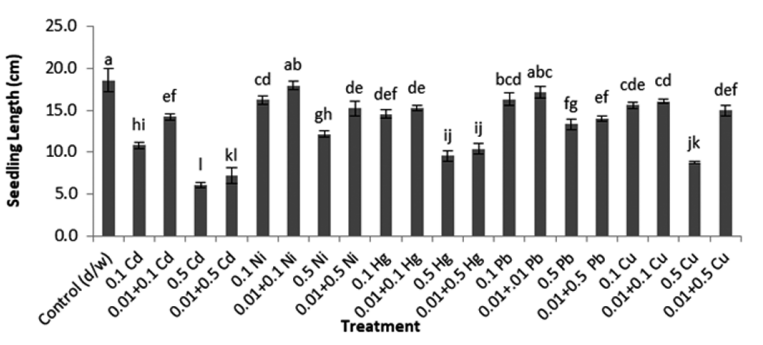

Fig. 2. Mean seedling length in mung bean ( $V$. radiata) after different concentrations of metal treatment at $p \leq 0.05$. Different letters represent significant difference placed over vertical bars of standard error $(n=3)$.

et al. 2011). Highest increase in alleviation was observed in $\mathrm{Ni}$ pretreatment with values of $3.5 \%$ and $18.2 \%$ respectively at 0.1 and $0.5 \mathrm{mM}$ concentration.

\section{Mitotic index}

The MI is important while calculating the root growth. Table 1 represents the mean sum of squares for the mitotic index and chromosomal abnormalities on root meristematic cells of mung bean after heavy metal stress. Our results showed that the significant reduction was observed in $\mathrm{MI}$ as a result of metal stress $(\mathrm{Cd}, \mathrm{Ni}$, $\mathrm{Hg}, \mathrm{Pb}$, and $\mathrm{Cu}$ ) in a concentration dependent manner. Highest MI was recorded in control with $88 \%$ (Fig. 1). Among all metals $\mathrm{Cd}(0.5 \mathrm{mM})$ showed higher toxicity with MI values $13.4 \%$ which was $84.8 \%$ inhibited as compared to control. Among all metals $\mathrm{Pb}$ and $\mathrm{Ni}$ were found to be less toxic. Similar observation about heavy metals $(\mathrm{Cd}$ and $\mathrm{Pb}$ ) was also reported (Siddiqui et al. 2009, Siddiqui 2012). Aidid and Okamoto (1992) reported that heavy metals suppress the elongation of the different plant cells that might be due to inhibition in mitosis thus reducing plant growth. The MI inhibition was in the following order of $\mathrm{Cd}>\mathrm{Hg}>\mathrm{Cu}>\mathrm{Pb}>\mathrm{Ni}$. Our results also showed that priming of seeds with mild concentration $(0.01 \mathrm{mM})$ of respective metals prior to high

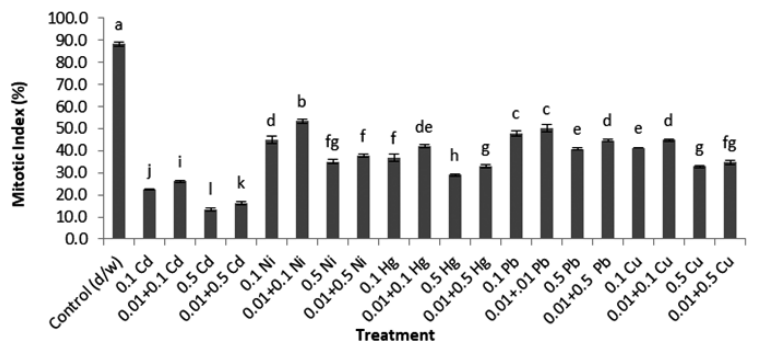

Fig. 3. Mean mitotic index of mung bean ( $V$. radiata) after different concentrations of metal treatment at $p \leq 0.05$. Different letters represent significant difference placed over vertical bars of standard error $(n=3)$.

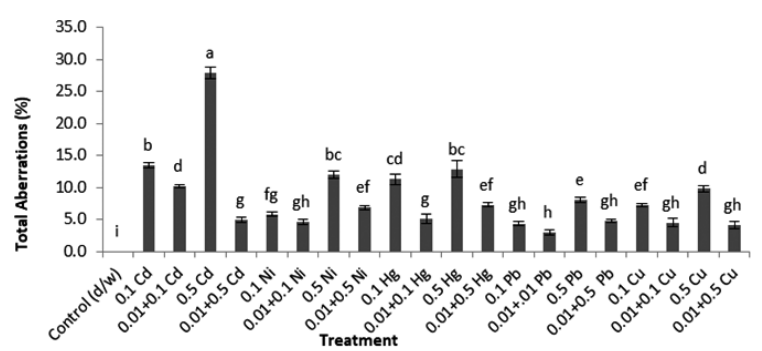

Fig. 4. Mean total aberrations in mung bean ( $V$. radiata) after different treatments of metal at $p \leq 0.05$. Different letters represent significant difference placed over vertical bars of standard error $(n=3)$.

metal treatments, relatively improves $\mathrm{MI}$ as compared to direct treatment with each metal separately. This could be the reason that plants make it self-ready for being exposed by a high concentration of metal by synthesizing/ increasing some proteins or enzymes. Similar work had already been proposed that seed priming found effective to increase the yield of legumes before sowing inland near the industrializing area (Rashid et al. 2004). It may also depend upon the mode of application (Bakht et al. 2011). 
Table 2. Mean values for different chromosomal aberrations (\%) in mung bean root tip cells under metal treatments.

\begin{tabular}{|c|c|c|c|c|c|c|}
\hline Treatment & Bridges & Stickiness & Laggards & C-mitosis & $\begin{array}{l}\text { Disturbed } \\
\text { metaphase }\end{array}$ & $\begin{array}{c}\text { Abnormal } \\
\text { prophase }\end{array}$ \\
\hline Control (d/w) & 0.00 & 0.00 & 0.00 & 0.00 & 0.00 & 0.00 \\
\hline $0.1 \mathrm{Cd}$ & 0.00 & $3.51 \pm 0.34^{\mathrm{a}}$ & $1.17 \pm 0.13^{\mathrm{b}}$ & $7.73 \pm 0.50^{\mathrm{b}}$ & $1.02 \pm 0.03^{\mathrm{d}}$ & 0.00 \\
\hline $0.01+0.1 \mathrm{Cd}$ & 0.00 & $3.38 \pm 0.31^{\mathrm{a}}$ & 0.00 & $6.76 \pm 0.20^{\mathrm{b}}$ & 0.00 & 0.00 \\
\hline $0.5 \mathrm{Cd}$ & 0.00 & $1.24 \pm 0.06^{\mathrm{efgh}}$ & $1.64 \pm 0.18^{\mathrm{a}}$ & $25.04 \pm 1.11^{\mathrm{a}}$ & 0.00 & 0.00 \\
\hline $0.01+0.5 \mathrm{Cd}$ & 0.00 & $2.41 \pm 0.27^{\mathrm{bc}}$ & 0.00 & $2.54 \pm 0.17^{\text {efg }}$ & 0.00 & 0.00 \\
\hline $0.1 \mathrm{Ni}$ & 0.00 & $1.98 \pm 0.50^{\mathrm{cd}}$ & 0.00 & $2.74 \pm 0.31^{\mathrm{efg}}$ & $1.09 \pm 0.15^{\mathrm{d}}$ & 0.00 \\
\hline $0.01+0.1 \mathrm{Ni}$ & 0.00 & $1.36 \pm 0.29^{\mathrm{efgh}}$ & 0.00 & $2.52 \pm 0.15^{\text {efg }}$ & $0.70 \pm 0.14^{\mathrm{d}}$ & 0.00 \\
\hline $0.5 \mathrm{Ni}$ & 0.00 & $1.85 \pm 0.31^{\mathrm{cde}}$ & $0.46 \pm 0.02^{\mathrm{d}}$ & $6.65 \pm 0.48^{\mathrm{b}}$ & $1.59 \pm 0.36^{\mathrm{bc}}$ & $1.41 \pm 0.05^{\mathrm{d}}$ \\
\hline $0.01+0.5 \mathrm{Ni}$ & 0.00 & $1.70 \pm 0.25^{\mathrm{def}}$ & 0.00 & $4.42 \pm 0.42^{\mathrm{cd}}$ & $0.72 \pm 0.15^{\mathrm{d}}$ & 0.00 \\
\hline $0.1 \mathrm{Hg}$ & 0.00 & $0.86 \pm 0.02^{\mathrm{gh}}$ & 0.00 & $2.71 \pm 0.10^{\mathrm{efg}}$ & $0.67 \pm 0.13^{\mathrm{d}}$ & $7.02 \pm 0.89^{\mathrm{a}}$ \\
\hline $0.01+0.1 \mathrm{Hg}$ & 0.00 & $0.79 \pm 0.15^{\mathrm{h}}$ & 0.00 & $1.30 \pm 0.40^{\mathrm{ghi}}$ & 0.00 & $2.99 \pm 0.46^{\mathrm{c}}$ \\
\hline $0.5 \mathrm{Hg}$ & $0.67 \pm 0.33^{b}$ & $3.02 \pm 0.21^{\mathrm{ab}}$ & $0.56 \pm 0.02^{\mathrm{cd}}$ & $7.81 \pm 0.97^{b}$ & $0.80 \pm 0.15^{\mathrm{d}}$ & 0.00 \\
\hline $0.01+0.5 \mathrm{Hg}$ & 0.00 & $2.11 \pm 0.41^{\mathrm{cd}}$ & 0.00 & $5.18 \pm 0.13^{\mathrm{c}}$ & 0.00 & 0.00 \\
\hline $0.1 \mathrm{~Pb}$ & 0.00 & $2.05 \pm 0.19^{\mathrm{cd}}$ & 0.00 & $2.29 \pm 0.36^{\mathrm{efg}}$ & 0.00 & 0.00 \\
\hline $0.01+0.1 \mathrm{~Pb}$ & 0.00 & $1.07 \pm 0.12^{\mathrm{fgh}}$ & 0.00 & $1.91 \pm 0.36^{\mathrm{fgh}}$ & 0.00 & 0.00 \\
\hline $0.5 \mathrm{~Pb}$ & 0.00 & $2.10 \pm 0.15^{\mathrm{cd}}$ & 0.00 & $0.65 \pm 0.11^{\mathrm{hi}}$ & 0.00 & $5.31 \pm 0.52^{b}$ \\
\hline $0.01+0.5 \mathrm{~Pb}$ & 0.00 & $1.55 \pm 0.13^{\mathrm{defg}}$ & 0.00 & 0.00 & 0.00 & $3.23 \pm 0.41^{\mathrm{c}}$ \\
\hline $0.1 \mathrm{Cu}$ & 0.00 & $1.12 \pm 0.09^{\text {efgh }}$ & $1.02 \pm 0.02^{b}$ & $3.53 \pm 0.29^{\mathrm{de}}$ & $1.61 \pm 0.09^{b c}$ & 0.00 \\
\hline $0.01+0.1 \mathrm{Cu}$ & 0.00 & 0.00 & 0.00 & $3.33 \pm 0.53^{\mathrm{def}}$ & $1.20 \pm 0.20^{\mathrm{cd}}$ & 0.00 \\
\hline $0.5 \mathrm{Cu}$ & $1.08 \pm 0.08^{\mathrm{a}}$ & $1.03 \pm 0.02^{\mathrm{fgh}}$ & $0.68 \pm 0.13^{\mathrm{c}}$ & $3.76 \pm 0.58^{\mathrm{de}}$ & $2.29 \pm 0.35^{\mathrm{a}}$ & $0.96 \pm 0.25^{\mathrm{d}}$ \\
\hline $0.01+0.5 \mathrm{Cu}$ & 0.00 & 0.00 & 0.00 & $2.37 \pm 0.28^{\mathrm{efg}}$ & $1.83 \pm 0.40^{\mathrm{ab}}$ & 0.00 \\
\hline
\end{tabular}

Table 3. Correlation between mean seedling length, percent mitotic index and chromosomal abnormalities on root meristematic cells of mung bean ( . radiata) at different concentrations of heavy metals.

\begin{tabular}{|c|c|c|c|c|c|c|c|c|}
\hline & $\begin{array}{c}\text { Total } \\
\text { aberrations }\end{array}$ & Bridges & Stickiness & Laggards & $\mathrm{C}$-mitosis & $\begin{array}{c}\text { Disturb } \\
\text { metaphase }\end{array}$ & $\begin{array}{c}\text { Abnormal } \\
\text { prophase }\end{array}$ & $\begin{array}{l}\text { Seedling } \\
\text { length }\end{array}$ \\
\hline Mitotic index & $-0.674 * *$ & -0.146 & $-.495 * *$ & $-.461 * *$ & $-.579 * *$ & -0.115 & 0.017 & $.783 * *$ \\
\hline Total aberrations & & 0.177 & $.303 *$ & $.777 * *$ & $.923 * *$ & 0.058 & 0.06 & $-.685^{* *}$ \\
\hline Bridges & & & 0.046 & 0.235 & 0.065 & $.445^{* *}$ & -0.057 & $-.389 * *$ \\
\hline Stickiness & & & & 0.169 & 0.192 & -0.219 & -0.121 & $-.390 * *$ \\
\hline Laggards & & & & & $.756 * *$ & $.265^{*}$ & -0.212 & $-.557 * *$ \\
\hline C-mitosis & & & & & & -0.034 & $-.250 *$ & $-.606^{* *}$ \\
\hline Disturb metaphase & & & & & & & -0.139 & -0.054 \\
\hline Abnormal prophase & & & & & & & & 0.035 \\
\hline
\end{tabular}

** Correlation is significant at the 0.01 level (2-tailed). ${ }^{*}$ Correlation is significant at the 0.05 level (2-tailed).

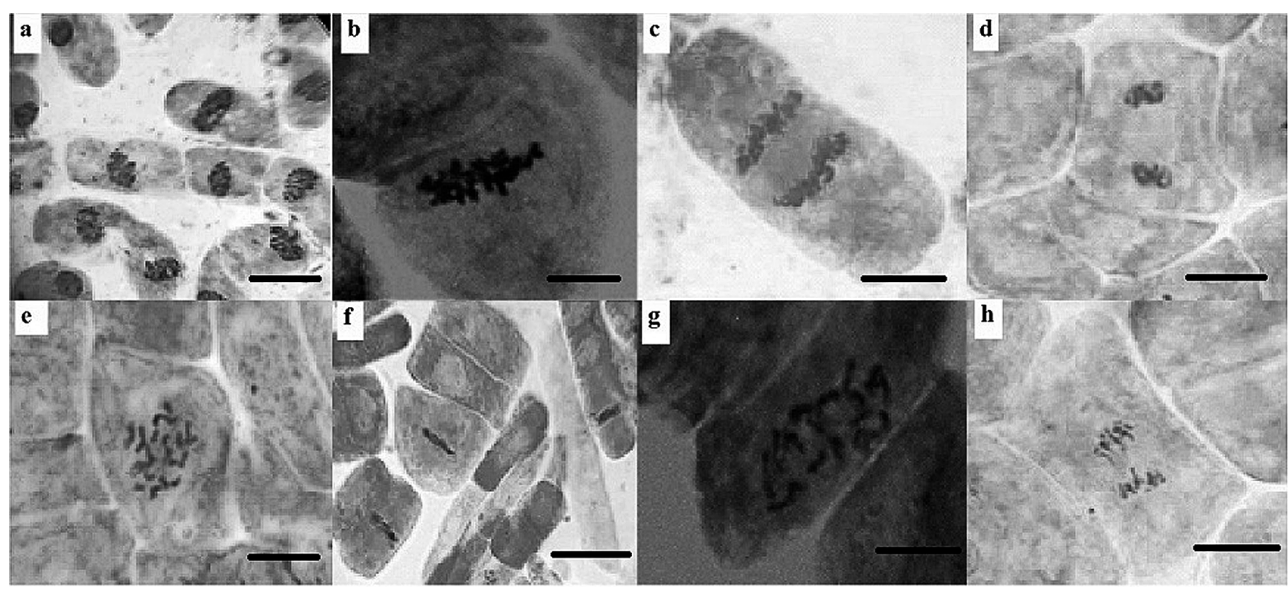

Fig. 5. Chromosomal aberrations in root tip cells of mung bean under various metal treatments. Normal: (a) prophase, (b) metaphase, (c) anaphase, (d) telophase. Abnormal: (e) C-mitosis, (f) sticky metaphase, (g) disturbed metaphase with disoriented chromosomes, (h) laggard anaphase. Scale bars in a and $\mathrm{f}=200 \mu \mathrm{m}$ and in others $=300 \mu \mathrm{m}$.

\section{Chromosomal aberrations}

During germination and growth, cells undergo division by entering into prophase, metaphase, anaphase, telophase, and ultimately splitted into two daughter cells. However this normal cell cycle is disturbed by the exposure of various abiotic stresses like heavy met- 
als and may lead to several chromosomal aberrations. Figure 4 showed that different types of chromosomal aberrations were established due to various heavy metals treatments through cytogenetic analysis that includes abnormal prophase, C-mitosis, disturb metaphase, stickiness, bridges formation and laggard chromosomes. Figure 4 demonstrated that total aberration was highest at $0.5 \mathrm{mM} \mathrm{Cd}(28 \%)$, but reduced to $0.5 \%$ when priming with $0.1 \mathrm{mM} \mathrm{Cd}$ was done before $0.5 \mathrm{mM} \mathrm{Cd}$ (Fig. 4). Our studies showed that all metals $(\mathrm{Cd}, \mathrm{Ni}, \mathrm{Hg}, \mathrm{Pb}$, and $\mathrm{Cu}$ ) were having various types of aberrations with different frequencies (Table 2). Stickiness and C-mitosis were frequently found in metal treatments. Aberrations were found in the following order $\mathrm{Ni}<\mathrm{Pb}<\mathrm{Cu}<\mathrm{Hg}<\mathrm{Cd}$. It was suggested that $\mathrm{Cd}$ may interact with chromatin proteins that lead to wrong coding of nonhistone proteins involved in chromosome organization that resulted in different cytogenetic abnormalities (Gaulden 1987) or alterations in cytochemical balanced reactions. It was reported earlier in pea roots that $\mathrm{Cd}$ was responsible for sticky chromosomes (Fusconi et al. 2007). Metals were responsible to denature nuclear proteins such as DNA topoisomerase II, that may interfere with chromosome segregation and resulted in metaphasic aberration (Panda and Panda 2002). C-mitosis is commonly associated with spindle dysfuntioning as reported by Shahin and El-Amoodi (1991). Dwiveedi and Kumar (2015) reported disturbing metaphase in Brassica campestris when exposed to sunset yellow food dye. $\mathrm{Pb}$ was also reported to interrupt DNA synthesis or even blockage of the cells at the $\mathrm{G}_{2}$ phase of the cell cycle thus restrict cells to enter mitosis (Eun et al. 2000). Laggard chromosomes were formed by disturbances in the spindle apparatus or the centromere. In this connection, it was said by Fiskesjo (1997) that the chromosome lagging was induced by a weak C-mitotic effect and they indicate a risk of aneuploidy. Lagged chromosomes might depend upon the moving speed and process of an individual chromosome differing from normal ones. According to research chromosomal stickiness, the failure of chromosomal separation and unequal translocation or inversion of chromatids was responsible for generating chromosomal bridges (Siddiqui 2012). Our results demonstrated that priming of seed with mild respective metals treatment significantly reduces the percentage of aberrations at both concentrations of metals. Table 3 represented that there is a highly significant correlation between seedling length and MI, whereas a highly negative correlation between seedling length and all aberrations so it showed genotoxicity of metals in mung bean. This table showed highly significant differences between $\%$ total aberrations and $\%$ stickiness, \% lagging chromosomes, and \% C-mitosis.

\section{Acknowledgements}

This research was funded by Dean Faculty of Science
Research Grant, University of Karachi. Authors extend their thanks to Pakistan Agricultural Research Center, Islamabad, Pakistan, for providing seeds of mung bean. Authors are also very thankful to Dr. Tabassum of National Nematological Research Center, Pakistan, for using a microscope and taking pictures.

\section{References}

Aidid, S. B. and Okamoto, H. 1992. Effect of lead, cadmium and zinc on the electric membrane potential at the xylem/symplast interface and cell elongation of Impatiens balsamina. Environ. Exp. Bot. 32: 439-448.

Bakht, J., Shafi, M., Jamal, Y. and Sher, H. 2011. Response of maize (Zea mays L.) to seed priming with $\mathrm{NaCl}$ and salinity stresses. Span. J. Agric. Res. 9: 252-261.

Beyersmann, D. and Hartwig, A. 2008. Carcinogenic metal compounds: recent inside into molecular and cellular mechanisms. Arch. Toxicol. 82: 493-512.

Dimitrova, I. and Ivanova, E. 2003. Effect of heavy metal-soil pollution on some morphological and cytogenetical characteristics of flax (Linumu sitatissum). J. Balk. Ecol. 6: 212-218.

Djingova, R. and Kuleff, I. 2000. Instrumental Techniques for Trace Analysis. In: Vernet, J. P. (ed.) Trace Elements: Their Distribution and Effects in the Environment. Elsevier, London. pp. 137-185.

Dwiveedi, K. and Kumar, G. 2015. Genetic damage induced by a food coloring dye (Sunset Yellow) on meristematic cells of Brassica campestris L. J. Environ. Public Health 2015: 319727.

Eun, S. O., Youn, H. S. and Lee, Y. 2000. Lead disturbs microtubule organization in the root meristem of Zea mays. Physiol. Plant. 110: $357-365$.

Farheen, J. and Mansoor, S. 2019. Cytogenetic impact of sodium chloride on root cells of Vigna radiata L. seedlings. Turk. J. Biochem. 45: https://doi.org/10.1515/tjb-2018-0352.

Fiskesjo, G. 1997. Assessment of a chemical's genotoxic potential by recording aberration in chromosomes and cell divisions in root tips of Allium cepa. Environ. Toxicol. Water Qual. 9: 235-241.

Fusconi, A., Gallo, C. and Camusso, W. 2007. Effects of cadmium on root apical meristem of Pisum sativum L: Cell viability, cell proliferation and microtubule pattern as suitable markers for assessment of stress pollution. Mutat. Res. Genet. Toxicol. Environ. Mutagen. 632: 9-19.

Gaulden, M. E. 1987. Hypothesis: Some mutagens directly alter specific chromosomal protein (DNA topoisomerase II and peripheral proteins) to produce chromosome stickiness which causes chromosome aberrations. Mutagenesis 2: 357-365.

Ishido, M. and Kunimoto, M. 2000. Regulation of cell fate by cadmium and zinc. J. Health Sci. 47: 9-13.

Jairajpuri, M., Raval, R. and Patel, K. 2016. Chromosomal aberrations in root meristems of Allium cepa L. induced by dyeing industrial effluent. Int. J. Multidiscip. Res. Dev. 3: 272-275.

Kumar, G. and Rai, P. 2007. Genotoxic potential of mercury and cadmium in soybean. Turk. J. Biol. 31: 13-15.

Liu, W., Yang, Y. S., Li, P. J., Zhou, Q. X., Xie, L. J. and Han, Y. P. 2009. Risk assessment of cadmium contaminated soil on plant DNA damage using RAPD and physiological indices. J. Hazard. Mater. 161: 878-883.

Muneer, S., Qadri, T. N. and Siddiqi, T. O. 2011. Cytogenetic and biochemical investigations to study the response of Vigna radiata to cadmium stress. Afri. J. Plant Sci. 5: 183-192.

Panda, B. B. and Panda, K. K. 2002. Genotoxicity and Mutagenicity of Metals in Plants. In: Prasad, M. N. V. and Strzalka, K. (eds.). Physiology and Biochemistry of Metal Toxicity and Tolerance in Plant. Springer, Dordrecht. pp. 395-414. 
Rajesh, D. and Radha, S. 2011. Effect of copper and zinc on physiological and biochemical parameters in Vigna mungo (L.). Hepper. Int. J. Pharm. Biol. Sci. 2: 554-565.

Rashid, A., Harris, D., Hollington, P. and Ali, S. 2004. On-farm seed priming reduces yield losses of mung bean (Vigna radiata) associated with mung bean yellow mosaic virus in NWFP of Pakistan. Crop Prot. 23: 1119-1124.

Samuel, O. B., Osuala, F. I. and Odeigah, P. G. C. 2010. Cytogenotoxicity evaluation of two industrial effluents using Allium cepa assay. J. Environ. Sci. Technol. 4: 21-27.

Shahin, S. A. and El-Amoodi, K. H. H. 1991. Induction of numerical chromosomal aberrations DNA synthesis using the fungicides nimrod and rubigan-4s Vicia faba L. Mutat. Res. 261: 169-176.

Siddiqui, S. 2012. Lead induced genotoxicity in Vigna mungo var. HD-94. J. Saudi Soc. Agric. Sci. 11: 107-112.

Siddiqui, S., Meghvansi, M. K., Wani, M. A. and Jabee, F. 2009. Evaluating cadmium toxicity to the root meristem of Pisum sativum L. Acta Physiol. Plant. 31: 531-536.

Sudhakar, C., Symalabai, L. and Veeranjaveyuler, K. 1992. Lead tolerance of certain legume species grown on lead or tailing. Agric. Ecosyst. Environ. 41: 253-261.

Unyayar, S., Celik, A., Cekic, F. O. and Gozel, A. 2006. Cadmium-induced genotoxicity, cytotoxicity and lipid peroxidation in Allium sativum and Vicia faba. Mutagenesis 21: 77-81. 